\title{
ANALISIS KESADARAN MASYARAKAT DALAM MITIGASI BENCANA TANAH LONGSOR DI DESA DAYAKAN KABUPATEN PONOROGO
}

\author{
Fendy Eko Hardiawan ${ }^{1}$, Ardhana Januar Mahardhani ${ }^{2}$ \\ ${ }^{12}$ Prodi Pendidikan Pancasila dan Kewarganegaraan, Universitas Muhammadiyah Ponorogo \\ Ponorogo, Indonesia \\ $\underline{\text { fendyeko20@gmail.com }}^{1}$, $\underline{\text { ardhana@umpo.ac.id }}^{2}$
}

\begin{abstract}
This study aims to determine public awareness in terms of 3 aspects namely Knowledge, Attitude, and Behavior in three stages of Disaster Mitigation, namely Pre-Disaster, Emergency Response, and PostDisaster.. The method used in this study is descriptive qualitative with data collection techniques of observation, interviews, and documentation, data analysis using the Miles and Huberman model, data reduction, data display, and data conclusions. The results of this research show: 1) public awareness in pre-disaster disaster mitigation; 2) public awareness in disaster mitigation at the emergency response stage; 3) public awareness in post-disaster disaster mitigation.
\end{abstract}

Keyword: Community Awareness, Disaster Mitigation, Pre-Disaster, Emergency Response, PostDisaster

\section{PENDAHULUAN}

Kabupaten Ponorogo adalah salah satu kabupaten yang berada di Provinsi Jawa Timur dengan jarak $193 \mathrm{~km}$ dari Ibukota Provinsi Jawa Timur. Kabupaten Ponorogo merupakan daerah yang memiliki 2 kondisi topografi dataran yakni dataran tinggi dan rendah. Dataran tinggi di Ponorogo merupakan gugusan pegunungan karts yang memiliki potensi bencana tanah longsor. Salah satu daerah rawan longsor yang ditetapkan oleh BPBD Kabupaten Ponorogo adalah Desa Dayakan yang terletak di Kecamatan Badegan.

Desa Dayakan memiliki luas 968,987 Ha, dengan penggunaan lahan untuk pemukiman penduduk 55,808 Ha, lahan untuk persawahan 351,287 Ha, Lahan kering 551,892 Ha. Kemudian untuk kondisi topografi Desa Dayakan adalah dataran rendah seluas $196,191 \mathrm{Ha}$, dataran tinggi seluas 762,796 Ha. (Profil Desa Dayakan Tahun 2019) Dengan kondisi topografi tersebut Desa Dayakan memiliki potensi untuk terjadinya bencana tanah longsor.

Dalam Dokumen Kajian Resiko Bencana Desa Dayakan yag disusun oleh BPBD Kabupaten Ponorogo bersama Forum PRB Desa, Dayakan memiliki beberapa ancaman kebencanaan. Resiko bencana Desa Dayakan dapat dilihat pada tabel berikut: 
Tabel 1. Ragam Ancaman Desa

Dayakan

\begin{tabular}{cll}
\hline No & \multicolumn{1}{c}{$\begin{array}{c}\text { Jenis } \\
\text { Ancaman }\end{array}$} & \multicolumn{1}{c}{ Ancaman } \\
& Ancaman & Gempa bumi, \\
\hline 1 & Ancaman & Gerakan Tanah, \\
& Geologi & Tanah Longsor \\
& & Kekeringan, \\
2 & Ancaman & Angin puting \\
& Hidrometer & beliung \\
& orologi & Wabah malaria, \\
3 & Ancaman & hama/penyakit \\
& Biologi & tanaman, \\
& & penyakit hewan \\
& & ternak \\
& & Kebakaran \\
& & Ancaman
\end{tabular}

(Mahardhani et al., 2021)

Dari data tersebut dapat diketahui bahwa ancaman bencana Desa Dayakan tidak hanya bencana alam, tetapi juga bencana non alam. Terjadinya bencana tidak dapat diprediksi dan dapat terjadi dimanapun dan kapanpun. Oleh karena itu perlu adanya sebuah kesadaran masyarakat untuk menjalankan mitigasi bencana, guna mengurangi dampak resiko jika sewaktuwaktu terjadi sebuah bencana di suatu wilayah. Kesadaran masyarakat merupakan sebuah cara dalam membentuk sebuah sistem mitigasi bencana yag efektif. Menurut Soekanto kesadaran meliputi 3 aspek yaitu pengetahuan, sikap dan perilaku (Kurniasari, 2016).

Kesadaran masyarakat terhadap mitigasi bencana sangat penting guna menekan resiko dari dampak terjadinya bencana. Tiga aspek yang disebutkan oleh soekanto tersebut menjadi sebuah indikator kesadaran bagi masyarakat. Pertama masyarakat perlu memiliki pengetahuan seputar kebencanaan, pengetahuan kebencanaan berarti masyarakat mampu memahami mulai dari ciri-ciri, tanda-tanda, ataupun hal-hal yang dapat menimbulkan atau menyebabkan bencana. Dari pengetahuan yang dimiliki masyarakat akan timbul sebuah sikap untuk mencegah atau meminimalisir halhal tersebut, ketika sebuah sikap sudah dilakukan secara terus-menerus maka akan muncul sebuah perilaku sadar bencana dimasyarakat. Masyarakat sadar bencana didefinisikan sebagai 'masyarakat yang mampu mengetahui, memahami, dan peduli terhadap hal-hal yang berkaitan dengan kebencanaan' (Sriharini, 2010).

Bencana menurut Rautela (2006) adalah 'sebuah kondisi kerusakan dan goncangan yang menyebabkan kerusakan pada struktur sosial masyarakat serta populasi yang terkena bencana tidak 
mampu mengatasi peristiwa tersebut dan membutuhkan bantuan pihak luar'(Kusumasari, 2014). Seperti kita ketahui bahwa bencana terjadi tidak dapat diprediksi waktu dan tempat terjadinya. Untuk mengurangi resiko akibat terjadinya bencana perlu adanya sebuah mitigasi bencana. Mitigasi Bencana adalah 'sebuah upaya yang dilakukan untuk mengurangi bahkan menghapus kerugian dan korban akibat terjadinya bencana' (Fadhli, 2019).

Perkembangan progesif penanggulangan bencana di Indonesia ditandai dengan munculnya UU No 24 Tahun 2007 tentang penanggulangan bencana. Dengan adanya Undang-undang tersebut adanya perubahan paradigma terhadap penanggulangan bencana di Indoensia. Paradigma lama yang bersifat reaktif, parsial, dan sektoral berubah menjadi proaktif dan holistik, dari insidental menjadi penanggulangan secara berencana, berkesinambungan, sejak pra bencana, tanggap darurat, dan pasca bencana(Sriharini, 2010).

Paradigma baru dalam penanggulangan bencana dimulai sejak pra bencana, masa tanggap darurat, dan bahkan pasca bencana. Ketiga poin tersebut merupakan hal penting dalam pelaksanaan mitigasi bencana secara efektif. Masyarakat dan pemerintah perlu menyiapkan ketiga kegiatan tersebut secara berkesinambungan, dan terencana.
Kegiatan mitigasi bencana memiliki tujuan 1) meminimalisir risiko dan dampak yang mungkin terjadi karena suatu bencana 2) sebagai pedoman pemerintah dalam membuat perencanaan pembangunan suatu wilayah 3) membantu meningkatkan kesadaran dan pengetahuan masyarakat dalam menghadapi risiko dan dampak bencana (Fadhli, 2019).

Salah satu potensi bencana di Desa dayakan adalah bencana tanah longsor. Terakhir bencana tanah longsor di Desa Dayakan terjadi pada bulan maret 2020 . bencana tanah longsor dan banjir bandang terjadi pada tanggal 3 maret 2020 di Dusun Jurangsempu Desa Dayakan. Bencana tanah longsor ini tidak menghasilkan korban jiwa, tetapi ratusan warga harus diungsikan (Kominfo, 2020).Dugaan penyebab longsor dayakan pada maret 2020 adalah hasil dari olah fungsi lahan yang dahulunya hutan desa diolah menjadi persawahan, hal ini menyebabkan air tidak dapat diserap secara sempurna,dan akhirnya ketika hujan lebat terjadi longsor dan banjir bandang.

Bencana tanah longsor dapat dapat terjadi karena dua faktor uatama, faktor tersebut adalah faktor pengontrol dan faktor pemicu. Faktor pengontrol adalah faktor-faktor yang memengaruhi kondisi material itu sendiri, seperti kemiringan lereng, litologi, kondisi geologi, sesar dan kekar batuan. Sedangkan faktor pemicu 
merupakan faktor-faktor yang memicu bergeraknya material tersebut, seperti curah hujan yang tinggi, gempa bumi, erosi lereng, dan aktivitas manusia (Naryanto et al., 2019).

Pada dasarnya sebuah bencana pasti terjadi, baik didaerah yang rawan atau tidak. Maka dalam hal ini masyarakat memiliki peran penting dalam hal manjemen bencana, minimal apabila bencana itu terjadi dapat diminimalisir dampak kerugian baik jiwa, ataupun properti bagi umat manusia. Kesadaran masyarakat sangat diperlukan dalam hal mengurangi dampak-dampak terjadinya bencana. dimulai dari pra bencana, tanggap darurat dan sampai pada pasca bencana.

Pada hasil penelitian yang dilakukan oleh (Kurniasari, 2016) tentang Kajian Tingkat Kesadaran Masyarakat Terhadap Bencana Tanah Longsor di Kecamatan Banjarmangu Kabupaten Banjarnegara Tahun 2015 ( Studi Non Fisik Mitigasi Bencana), menunjukkan bahwa dari aspek pengetahuan masyarakat dinilai cukup mengetahui penyebab, dan cara mengurangi resiko bencana tanah lonsor. Sedangkan dari aspek sikap masyarakat masyarakat dinilai sangat baik, karena menerima dan mempunyai keinginan menjalankan mitigasi bencana tanah longsor, tetapi dalam beberapa faktor masyarakat menolak dalam hal penanaman pohon berakar keras, dan pembangunan bangunan di lereng. Kemudian untuk aspek perilaku masyarakat dinilai kurang, karena dalam perilaku kesehariannya masih belum menjalankan mitigasi bencana tanah longsor secara baik dan optimal.

Selanjutnya hasil penelitian yang dilakukan oleh (Sriharini, 2010) tentang Membangun Masyarakat Sadar Bencana, menunjukkan bahwa masyarakat sadar bencana adalah masyarakat yang memiliki pengetahuan, pemahaman, ketrampilan, dan kepedulian dengan hal-hal kebencanaan, ketika masyarakat sadar bencana diharapkan dapat meminimalisir dampak bencana, kemudian untuk membangun masyarakat sadar bencana perlu diadakannya pendidikan kebencanaan.

Pada penelitian ini penulis ingin mengetahui bagaimana kesadaran masyarakat Desa Dayakan dalam mitigasi bencana tanah longsor, dan upaya masyarakat dalam melakukan mitigasi bencana tanah longsor. Kemudian penelitian ini bertujuan untuk mengetahui tkesadaran masyarakat yang ditinjau dari 3 aspek indikator yakni pengetahuan, sikap, dan perilaku terhadap mitigasi bencana yang meliputi pra bencana, tanggap darurat, dan pasca bencana. kemudian dari penelitian ini diharapkan akan memunculkan sebuah kebijakan strategis 
dari pemerintah desa terkait kebencanaan. Selain itu penelitian in juga bertujuan untuk mengetahui sejauh mana upaya masyarakat dalam melakukan mitigasi bencana tanah longsor di Desa Dayakan Kabupaten Ponorogo.

\section{METODE PENELITIAN}

Penelitian ini menggunakan pendekatan Deskriptif Kulitatif. Penelitian kuantitatif digunakan untuk meneliti pada kondisi objek yang alamiyah (Sugiyono, 2009), sedangkan deskriptif berarti data yang diperoleh berdasarkan faktor-faktor yang dapat menjadi pendukung terhadap objek penelitian kemudian faktor - faktor tersebut dianalisa guna mencari peranannya (Suharsimi Arikunto, 2010). Teknik pengumpulan data dalam penelitian ini menggunakan trianggulasi Data yakni Observasi, Wawancara, dan Dokumentasi. Observasi dilakukan secara langsung dilapangan selama 2 bulan, Wawancara dilakukan kepada kelompok DESTANA DESA, Perangkat Desa dan Warga Masyarakat, Dokumentasi dilakukan dengan mengumpulkan berkasberkas pendukung, dan foto dilapangan.

Analisis data menggunakan model Miles and Huberman, yakni analisis data dilakukan secara terus menerus dan menggunakan tahapan data reduction, data display, dan data conclusion (Sugiyono, 2009). Data hasil penelitian kemudian disajikan dalam bentuk deskriptif

\section{HASIL DAN PEMBAHASAN}

Kesadaran masyarakat memiliki 3 aspek yakni pengetahuan, sikap, dan perilaku. Pengetahuan menurut Djaali (Hendrawan \& Sirine, 2017) ialah kemampuan kognitif dalam mengingat, menghafal atau melakukan pengulangan suatu yang telah diresapi dan ditangkap. Proses terciptanya pengetahuan ini berarti masyarakat telah menerima informasi, ataupun melakukan sesuatu yang telah diresapi ataupun ditangkap oleh panca indera. Pengetahuan akan muncul ketika seorang manusia menggunakan akal budinya untuk menyikapi atas kejadian yang belum pernah dilihat ataupun ditemukan sebelumnya (Ghoni, 2015).

Pengalaman atau kejadian bencana alam bisajadi oleh segenap masyarakat merupakan sebuah hal yang baru, dengan munculnya kejadian tersebut masyarakat akan terdorong untuk mencari ataupun menggunakan akal budinya untuk menyikapi bencana alam tersebut. Masyarakat akan berusaha untuk mencari tahu langkah-langkah seperti apa untuk bertahan dalam kondisi bencana jika bencana itu terjadi. Hal-hal tersebut adalah sebuah bentuk penyesuaian diri yag dilakukan oleh masyarakat. Menurut Choirudin (Januar Mahardhani, 2020) 
penyesuaian diri memiliki dua aspek yakni penyesuaian pribadi dan penyesuaian sosial.

Penyesuaian pribadi merupakan bentuk penyesuaian diri terhadap kejadiankejadian baru, sedangkan penyesuaian sosial diartikan bahwa masyarakat sudah harus siap akan sesuatu hal yang terjadi. Pada dasarnya masyarakat sebagai individu haru menyesuaiakan diri dengan keadaan bahwasannya bencana tanah longsor memiliki potensi tinggi untuk bisa erjadi di Desa Dayakan, kemudian masyarakat secara sosialpun harus dapat menyesuaikan diri juga dengan keadaan yang sebenarnya.

Dalam ranah ini setelah masyarakat memiliki pengetahuan yang baik mengenai kebencanaan dan cara penanggulangan serta pengurangan resikonya akan muncul sebuah sikap yang mengharuskan masyarakat untuk bersama-sama menyesuaikan diri dalam kondisi yang ada. Dengan adanya pengetahuan akan muncul sebuah sikap dan perilaku masyarakat yang menunjukkan bahwa masyarakat sadar akan pentingnya mitigasi bencana. dengan adanya pengetahuan menjadi hal penting sebagai pintu masuk yang strategis untuk membangun budaya masyarakat yang peduli pada hal-hal yang berkaitan soal kebencanaan (Sriharini, 2010).
Kesadaran masyarakat dalam mitigasi bencana tanah longsor ini dapat ditempuh dalam beberapa aspek 1) Kesadaran Masyarakat Dalam Mitigasi Bencana Tahap Pra Bencana 2) Kesadaran Masyarakat Dalam Mitigasi Bencana Tahap Tanggap Darurat 3) Kesadaran Masyarakat Dalam Mitigasi Bencana Tahap Pasca Bencana. Berikut siklus penanggulangan bencana yang dirumuskan oleh BNPB :

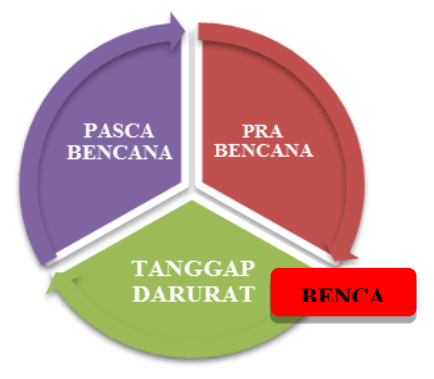

Gambar 1. Siklus Mitigasi Bencana

Sumber: Peraturan Kepala BNPB No 4 Tahun 2008 Tentang Pedoman Penyusunan Penanggulangan Bencana (BNPB, 2008)

Kesadaran Masyarakat Dalam Mitigasi Bencana Tahap Pra Bencana

Mitigasi bencana pada tahap pra bencana ini difokuskan agar masyarakat mempunyai pengetahuan, sikap dan perilaku pada saat pra bencana. mitigasi bencana pada tahap ini dapat dilakuakan dalam dua bentuk yakni bentuk terstruktur dan non-struktur, mitigasi terstruktur bisa dilakukan dalam bentuk memperkokoh struktur bangunan, desain atupun membuat penahan longsor, sedangkan upaya non struktur dapat dilakukan dalam bentuk 
masyarakat menghindari tempat-tempat yang rawan bencana (Suwaryo \& Yuwono, 2017). Menurut (Setyowati, 2019) Bentukbentuk kegiatan yang dapat dilakukan masyarakat pada tahap pencegahan bencana tanah longsor antara lain :

1) Pemetaan Kondisi Tanah

2) Pemetaan kondisi air, drainase dll

3) Menanam pepohonan dengan akar kuat (Reboisasi)

4) Tidak membangun bangunan di lereng gunung yang memiliki kounter tanah yang labil

5) Mengidentifikasi jika terjadi retakan kecil

6) Membuat rekayasa penanganan retakan kecil dengan tiang pancang, penahan tanah

Dari hasil penelitian di Desa Dayakan diketahui 3 aspek kesadaran dalam tahap Pra Bencana 3 Aspek tersebut meliputi :

\section{a. Aspek Pengetahuan Pra Bencana}

Berdasarkan hasil penelitian diketahui bahwa masyarakat Desa Dayakan mempunyai pengetahun yang cukup tentang mitigasi bencana, pengetahuan tersebut misalkan saja Masyarakat mengetahui bahwa menanam pohon berakar kuat adalah bentuk pencegahan dari bencana tanah longsor, dan membangun bangunan dilereng gunung yag labil juga merubapakan hal-hal yang perlu dihindari.

\section{b. Aspek Sikap Pra Bencana}

Masyarakat Desa Dayakan memiliki sikap yang setuju dalam pencegahan kebencanaan, tapi dalam implikasi dilapangan sebagian kecil masyarakat kurang setuju dalam hal penggantian tanaman yang produktif diganti dengan tanaman yang memiliki akar keras untuk menahan tanah dan air. seringkali apabila pihak Desa menanam pohon berakar kuat pohon tersebut habis di babat untuk pakan ternak. Di Desa Dayakan ini belum ada sebuah sistem atau aturan tertulis terkait penataan bangunan dan perencanaan pembangunan agar masyarakatmasyarakat ini dapat menghindari ataupun pengurangan resiko tanah longsor.

\section{c. Aspek Perilaku Pra Bencana}

Perilaku yang nampak pada masyarakat Desa Dayakan dalam hal mitigasi bencana tahap Pra bencana dapat dilihat dari Kebijakan Pemerintah Desa untuk membentuk Forum Pengurangan Resiko Bencana ( PRB). Forum ini digunakan untuk mendukung dan mensukseskan progam mitigasi bencana dan sebagai bentuk luaran dari terwujudnya Desa Tangguh Bencana. Forum ini menjadi salah satu kebijakan dari Pemerintah Desa dan BPBD sebagai pemerintah daerah dalam hal memberikan edukasi terkait mitigasi 
bencana kepada masyarakat dan menjadi kepanjangan tangan BPBD dalam hal mitigasi bencana ditingkat desa. Forum PRB ini sebagai forum advokasi, fasilitasi, konsultasi, dan monitoring dari BPD dalam progamprogam mitigasi bencana (Lestari \& Alhadi, 2020). Perilaku-perilaku masyarakat Desa Dayakan dalam melakukan mitigasi bencana tahap pra bencana selain tergabungnya dalam forum PRB, masyarakat juga telah melakuakan penanaman pohon secara mandiri di bukit belakang rumah, masyarakat juga telah membuat penahan-penahan tanah disamping rumah yang terdapat lereng-lereng tanah, selain itu ketika hujan lebat masyarakat selalu waspada dan sedia cangkul untuk membuat drainase air agar air menngalir dengan baik. Ada sebagain kecil masyarakat yang belum mencerminkan perilaku mitigasi bencana dalam tahapan pencegahan bencana ini, seperti masyarakat masa bodoh mengenai pentingnya penanaman pohon akr keras, masyarakat cenderung akan sadar jika bencana sudah terjadi dan meimpa dirinya ataupun keluarga.

\section{Kesadaran Masyarakat Dalam Mitigasi}

\section{Bencana Tahap Tanggap Darurat}

Kondisi Tanggap darurat adalah kondisi ketika suatu bencana terjadi.
Dalam kondisi masyarakat dituntut untuk bisa dan ahli dalam melakukan penyelamatan diri. Dalam proses mitigasi bencana ini menggunakan paradigma baru, yakni yang dulu bersifat insidental, berubah menjadi berencana, dan berkesinmabungan, sejak pra bencana, tanggap darurat, dan pasca bencana (Hartoyo, 2017).

Saat terpenting dalam proses tanggap darurat dimana masyarakat ini mempunyai kesiapsiagaan dalam menghadapi sebuah bencana, selain itu pendidikan mengenai mitigasi bencana juga menjadi hak yang baik. Dengan pendidikan kebencanaan, diharapkan citacita masyarakat dunia dapat terwujud, sehingga dapat menjalani kehidupan dengan aman dan tenteram. Dalam keadaan tanggap darurat dan mitigasi bencana perlu adanya sebuah sistem komunikasi. manajemen informasi untuk mitigasi bencana dapat dilakukan dengan bentuk : 1) adanya informasi mengenai resiko dan pemilihan pelindungan bencana yang mudah dipahami, 2) terjalinnya komunikasi yang kuat antar ahli bencana, pejabat, untuk menyusun rencana pengurangan resiko bencana, 3) Menerapkan sistem informasi terkini, 4) Adanya sistem informasi secara lokal (Hartoyo, 2017)

Dengan adanya pelatihan ataupun pendidikan untuk masyarakat akan 
mempermudah masyarakat dalam menjalani sistem tanggap darurat. Tanggap darurat sendiri adalah sebuah sikap untuk untuk mengantisipasi hal-hal yang tidak diinginkan ketika bencana terjadi, baik yang meimbulkan kerugian fisik, materil, mentalataupun spirituil (Aditiansyah \& Mahawati, 2014). Dalam hal ini kondisi tanggap darurat dapat dibangun atas dasar pengetahuan masyarakat megenai hal-hal untuk menyelematkan diri jika bencana terjadi, minimal kegiatan yang dapat ditempuh yakni sistem peringatan dini bencana, dan cara-cara menyelamatkan diri jika bencana terjadi.

\section{a. Aspek Pengetahuan Tanggap}

\section{Darurat}

Masyarakat Desa Dayakan telah mendapatkan pendidikan ataupun sosialisasi dari Forum PRB Desa terkait cara penyelamatan diri saat bencana terjadi, dengan hal tersebut masyarakat desa Dayakan telah mengetahui bagaimana langkah-langkah untuk memnimalisir resiko yang terjadi saat bencana terjadi. Masyarakat Desa Dayakan telah mengetahui cara penyelematan diri jika terjadi bencana, sosialisasi dan simulasi jika terjadi bencana telah disampaikan oleh Forum PRB, BPBD, dan pemerintah Desa.

\section{b. Aspek Sikap Tanggap Darurat}

Dalam menyikapi bencana masyarakat selalu siapsiaga. Dalam menyikapi kondisi yang dapat menimbulkan bencana terjadi masyarakat selalu siapsiaga dan selalu waspada dalam menyikapinya. Seperti yang disampaikan diatas masyarakat selalu sedia cangkul ketika hujan lebat melanda desa dayakan, selain itu masyarakat juga telah menyiapkan jalur-jalur-jalur evakuasi untuk mempermudah akses penyelamatan diri jika terjadi bencana sewaktu-waktu.

\section{c. Aspek Perilaku Tanggap Darurat}

Di Desa Dayakan telah dibangun sebuah sistem mitigasi bencana berbasis aplikasi android, yang bernama aplikasi Dayakan Mitigation Center ( DMC). Aplikasi ini merupakan hasil dari pengabdian mahasiswa Fakultas Keguruan dan Ilmu Pendidikan Univesritas Muhammadiyah Ponorogo melalui progam PHP2D dari KEMENDIKBUD RI tahun 2020. Fitur-fitur yang ada dalam aplikasi ini diantaranya 1) kenal bencana, 2) Cegah Bencana, 3) Lapor bencana, 4) Berita BPBD, 5) Panic Button, 6) SIG Desa Dayakan, 7) dan Hubungi Admin, berikut gambaran fitur Aplikasi DMC : (Mahardhani et al., 2021) 


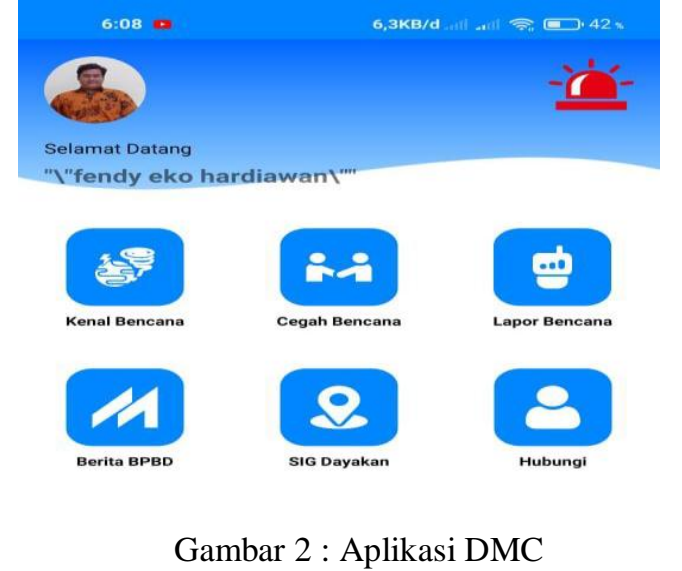

Dengan aplikasi ini Desa Dayakan berusaha membentuk sebuah sistem informasi yang terintegrasi dan membentuk sebuah sistem peringatan dini bencana yang cepat. Sebelum adanya aplikasi ini masyarakat menggunakan TOA Masjid untuk memperingatkan masyarakat lain bahwa ada bencana.. Kemudian Pemerintah Desa melalui APBDes melakukan penganggaran untuk pembiayaan dari rencana-rencana yang telah disusun oleh forum PRB Desa dalam hal mitigasi bencana, anggaran yang dianggarankan oleh Pemerintah Desa sekitar Rp 20.000.000 setiap tahunnya.

Selain adanya sistem peringatan dini, di Desa Dayakan juga dibangun posko bencana yang difokuskan pada satu titik yakni di Balai Desa, dengan adanya posko ini diharapkan penanganan korban segera bisa dilakukan.

\section{Kesadaran Masyarakat Dalam Mitigasi Bencana Tahap Pasca Bencana}

Pemulihan bencana ialah penormalan kehidupan masyarakat yang telah terdampak bencana(Kurniati et al., 2021). Pemulihan bencana ini dapat berupa rehabilitasi dan rekontruksi (Triwibowo et al., 2019). Rehabilitasi dalam KBBI diartikan sebagai perbaikan anggota tubuh yang cacat dan sebagainya atas individu (misalnya korban bencana) supaya menjadi manusia yang berguna dan memiliki tempat di masyarakat, sedangkan rekontruksi ialah pengembalian semuala (KBBI, 2016)

Pemulihan pasca bencana akan efektif jika masyarakat ikut andil dalam proses perencanaan yang mengarah kepada keberfungsian pemulihan secara menyeluruh yang menjadi bagian dari mitigasi bencana serta terlibat aktif dalam pelaksanaannya (Lindell, 2013). Pemulihan bencana tidak hanya berbicara mengenai pemulihan prasarana umum, rumah masyarakat, ataupun daerah lingkungan bencana, tetapi meliputi aspek ekonomi, psikologis, budaya, keamanana, fungsi pemerintahan, kesehatan, dll yang menyasar pada normalisasi kehidupan masyarakat yang terdampak bencana (Ramli, 2010).

Untuk pemulihan pasca bencana perlu adanya sebuah tahap perencanaan dan peran aktif masyarakat dalam 
menormalkan kembali kehidupan masyarakat yang terdampak bencana. Dalam makrosistem rehabilitasi dan rekontruksi dipresentasikan pada ranah kebijkan pemerintah, kearifan lokal, keagamaan dalam memberikan dukungan, dan perlindungan keamanan. (Kurniati et al., 2021).

\section{a. Aspek Pengetahuan Pasca Bencana}

Masyarakat Desa Dayakan memilik pengetahuan mengenai pemulihan pasca bencana ini soal mereka dapat menjalani kehidupan lagi dengan normal setelah bencana terjadi.

\section{b. Aspek Sikap Pasca Bencana}

Masyarakat Dayakan sangat
mendukung dan setuju megenai
pemulihan pasca bencana.

\section{c. Aspek Perilaku Pasca Bencana}

Dalam bencana tanah longsor di tahun 2020 silam, Pemulihan Pasca bencana di Desa Dayakan dilakukan secara terintegrasi baik dari pemerintah Desa sampai Daerah ikut andil dalam proses tersebut. Mulai dari pembangunan, pemulihan trauma dll telah dilakukam Pemerintah Desa melalui Forum PRB, BPBD, dan stakholder terkait. Bentuk pemulihan yang dilakukan dianaranya ialah, membangun akses jalan yang sempat terputus, mengeruk tanah yang menimbun disaluran irigasi, pemulihan kesehatan masyarakat, pemulihan ekonomi masyarakat dengan memberikan bantuan ekonomi, hingga penelitian ini ditulis masyarakat Dayakan telah berkehidupan secara normal kembali pasca bencana.

Dengan adanya kejadian diTahun 2020 membuat masyarakat Dayakan lebih waspada dengan gejala-gejala bencana, dibulan Juli 2021 ini Desa Dayakan dibangun pendeteksi gempa bumi, dan sistem kelistrikan berbasis tenaga surya yang akan sangat memebantu jika bencana terjadi.

Pemerintah Desa melalui APBDes juga telah membuat perencanaan terkait pemulihan bencana, yang mana anggaran tersebut dapat diambil sewaktu-waktu terjadi bencana. Perencanaan dan tindak lanjut yang cepat dalam Pemulihan pasca bencana merupakan hal penting dan termasuk bagian dari mitigasi bencana. Perencanaan - perencanaan yang dilakukan Pemerintah Desa tertuang dalam RPJMDes (Rencana Pembangunan Jangka Menengah Desa) dan Perdes, serta penganggaran dibebankan pada APBDes.

\section{KESIMPULAN}

- Berdasarkan hasil penelitian dan pembahasan dapat disimpulkan dari ketiga aspek kesadaran pada tahap Pra Bencana, Tanggap Darurat, dan Pasca Bencana sebagai berikut : 
a. Pengetahuan

Masyarakat telah mengetahui mengenai hal-hal apasaja yang perlu dilakukan dalam mitigasi bencana, baik dari pra bencana, tanggap darurat, dan pasca bencana.

b. Sikap

Dari sikap masyarakat Dayakan mendukung dan setuju atas segala aktivitas mengenai mitigasi bencana, walaupun sebagian kecil masyarakat Dayakan belum begitu setuju atas perubahan-perubahan yang harus dilakuakn terutama tahap pra bencana

c. Perilaku

Perilaku masyarakat Desa Dayakan juuga telah mencerminkan sebuah perilaku mitigasi bencana, baik dari pemerintah dan masyarakat secara indvidu telah melakukan hal-hal untuk mendukung tahap mitigasi bencana baik dari tahap prabencaa, tanggap darurat, dan pasca bencana

\section{DAFTAR PUSTAKA}

Aditiansyah, I., \& Mahawati, E. (2014). Hubungan antara Tingkat Pengetahuan Penghuni dan Fasilitas Rumah Susun Terhadap Kesiapan Tanggap Darurat Bencana Kebakaran di Rumah Susun Pekunden Kota Semarang. Skripsi: Fakultas Kesehatan Universitas Dian Nuswantoro.

BNPB. (2008). Peraturan Kepala BNPB No 4 Tahun 2008 Tentang Pedoman Penyusunan Penanggulangan Bencana.
Fadhli, A. (2019). Mitigasi Bencana (1st ed.). Gava Media.

Ghoni, H. A. (2015). PENGARUH MOTIVASI DAN PENGETAHUAN WAJIB PAJAK TERHADAP KEPATUHAN WAJIB PAJAK DAERAH. 1(1), 1-14.

Hartoyo, H. (2017). Membangun Masyarakat Sadar Bencana. TASYRI': JURNAL TARBIYAH-SYARI'AH ISLAMIYAH, 24(2), 28-35.

Hendrawan, J. S., \& Sirine, H. (2017). Pengaruh Sikap Mandiri, Motivasi, Pengetahuan Kewirausahaan Terhadap Minat Berwirausaha (Studi Kasus pada Mahasiswa FEB UKSW Konsentrasi Kewirausahaan). Asian Journal of Innovation and Entrepreneurship, 02(03), 291-314.

Januar Mahardhani, A. (2020). Menjadi Warga Negara yang Baik pada Masa Pandemi Covid-19: Persprektif Kenormalan Baru. Jurnal Pancasila Dan Kewarganegaraan, 5(2), 65-76. https://doi.org/10.24269/jpk.v5.n2.2020. pp65-76

KBBI. (2016). KAMUS BESAR BAHASA INDONESIA.

Kominfo. (2020). Longsor Dayakan, Pemkab Ponorogo Kirim Bantuan Untuk Pengungsi. Www.Ponorogo.Go.Id. https://ponorogo.go.id/2020/03/20/longso r-dayakan-pemkab-ponorogo-kirimbantuan-untuk-pengungsi/

Kurniasari, N. (2016). KAJIAN TINGKAT KESADARAN MASYARAKAT TERHADAP MITIGASI BENCANA TANAH LONGSOR DI KECAMATAN BANJARMANGU KABUPATEN BANJARNEGARA TAHUN 2015. Universitas Negeri Semarang.

Kurniati, E., Sari, N., \& Nurhasanah, N. (2021). Pemulihan Pascabencana pada Anak Usia Dini dalam Perspektif Teori Ekologi. Jurnal Obsesi: Jurnal Pendidikan Anak Usia Dini, 6(2), 579587.

Kusumasari, B. (2014). Manajemen bencana dan kapabilitas pemerintah lokal. CV. Gava Media.

Lestari, A., \& Alhadi, Z. (2020). Pendukung 
Dan Penghambat Efektivitas Kapasitas Kelembagaan Badan Penanggulangan Bencana Daerah Provinsi Sumatera Barat Dalam Pengurangan Risiko Bencana. Journal of Civic Education, 3(4), 360366.

Lindell, M. K. (2013). Recovery and Reconstruction After Disaster BT Encyclopedia of Natural Hazards (P. T. Bobrowsky (ed.); pp. 812-824). Springer Netherlands. https://doi.org/10.1007/9781-4020-4399-4_285

Mahardhani, A. J., Imamudin, I. A., \& Hardiawan, F. E. (2021). Upaya Mitigasi Bencana Melalui Aplikasi Dayakan Mitigation Center (DMC). Jurnal Pemberdayaan Masyarakat Universitas Al Azhar Indonesia, 3(2), 52. https://doi.org/10.36722/jpm.v3i2.560

Naryanto, H. S., Soewandita, H., Ganesha, D., Prawiradisastra, F., \& Kristijono, A. (2019). Analisis Penyebab Kejadian dan Evaluasi Bencana Tanah Longsor di Desa Banaran, Kecamatan Pulung, Kabupaten Ponorogo, Provinsi Jawa Timur Tanggal 1 April 2017. Jurnal Ilmu Lingkungan, 17(2), 272. https://doi.org/10.14710/jil.17.2.272-282

Ramli, S. (2010). Pedoman praktis manajemen bencana. Dian Rakyat.

Setyowati, D. L. (2019). Pendidikan Kebencanaan. Universitas Negeri Semarang.

Sriharini. (2010). Membangun Masyarakat Sadar Bencana. Jurnal Dakwah, 11(2), 157-171.

Sugiyono. (2009). METODE PENELITIAN KUANTITATIF KUALITATIF DAN $R \& D$.

Suharsimi Arikunto. (2010). Prosedur Penelitian Suatu Pendekatan Praktik. Jakarta: Rineka Cipta; 2010. Community Psychology.

Suwaryo, P. A. W., \& Yuwono, P. (2017). Faktor-faktor yang mempengaruhi tingkat pengetahuan masyarakat dalam mitigasi bencana alam tanah longsor. Urecol 6th, 305-314.

Triwibowo, B. S., Midhio, I. W., \& Nuriada, W. (2019). PERAN BATALYON ZENI
TEMPUR TNI AD PADA PHASE PEMULIHAN BENCANA GEMPA BUMI (STUDI PENUGASAN YONZIPUR 3/YW DI

PANGANDARAN). Strategi Pertahanan Darat, 5(1). 